\section{SAL 30/2017}

Impact of Englishon the Indonesian Language and Culture: High School Students' Perceptions

Received 02/2017 Accepted 05/2017

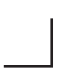

\section{Anglu kalbos jitaka indoneziečių kalbai ir kultūrai: kaip ją suvokia vidurinès mokyklos (gimnazijos)moksleiviai}

\section{SOCIOLINGUISTICS / SOCIOLINGVISTIKA}

\section{Elisabet Titik Murtisari}

PhD, senior lecturer, Universitas Kristen Satya Wacana, Central Java, Indonesia.

\section{Yustinus Calvin Gai Mali}

Lecturer, Universitas Kristen Satya Wacana, Central Java, Indonesia.

$\Gamma$ erossef http://dx.doi.org/10.5755/j01.sal.0.30.17570

With the advances of globalisation and technology, English dominates international politics, the economy and culture. Spoken by over a quarter of the world's population and enhanced by the presence of the Internet, it enjoys an unparalleled dominance in global communication and has affected people's lives across the globe.This study explores the perception of Indonesian high school students towards the impact of English on the Indonesian language and culture amids concerns about the hegemony of the international language and the country's efforts to maintain its national language. As many as 333 students from five schools in Salatiga, Central Java, participated in this research by filling out a Likert-scaled questionnaire. Unlike previous studies investigating a similar issue in the context of Indonesia, the study demonstrates strongly divided responses from the participants towards English. The students' religions and majors were also shown to be significant factors affecting the responses. Conducted on a wider scope, this research overall reveals stronger perceived tensions between the national language/culture and English than what has been demonstrated in previous research.

KEYWORDS: perception, impact of English, high school students, language, culture. 
With the advances of globalisation and technology, English dominates international politics, the economy and culture. Spoken by over a quarter of the world's population and enhanced by the presence of the Internet, it has indeed become "the operating system of the global conversation" (Robson, 2013, p.2) and has inevitably influenced people's lives across the globe. Amid this dominance, there have been concerns about the impact of English on other languages with which it has contact. Harmer (2007, p.16) specifically points out that "as more and more people speak English, languages will gradually be lost". For Indonesia, however, the implications of English on Indonesian, its national language, "may be more far-reaching" due to its central role for the country's unity (Onishi, 2011, par. 6). This language has been promoted by "generations of political leaders [...] to unite the highly diverse nation and forge a national identity out of countless ethnic groups, ancient cultures and disparate dialects" (ibid).

There have been apparent doubts about the state of the Indonesian language due to the effects of English. Gunarwan (1998), in one of the most cited works that bring up this issue, identifies English as a factor, which constrains Indonesian language learning because Indonesians tend to associate the former with high status and prestige. Sugiharto (2002) and Sadtono (2013) are also concerned that English seems to have influenced Indonesian a great deal, especially with its loanwords. So alarming the level appears to be that Sadtono (2013, p.61) believes the Indonesian language has suffered from an "onslaught of English words" - it is an "English tsunami". This anxiety about the impact of English seems to be gravely shared by the Indonesian government. It has recently reduced the amount of English taught in the senior high school curriculum after finding that more students obtained better scores for English than Indonesian in the national examination (Ujian Nasional).

Considering all the above, it is important to find out what Indonesian people, especially high school students, really think of English in regard to their national language and culture. As the younger generation, they are, borrowing Hassall et al.'s (2008, p.70) words, "the main future determiners of the influence of English on the language". While research has been conducted in this specific area (Dewi, 2014; Hassall et al., 2008), it has been very little, and none has involved a substantial number of respondents nor addressed the perception of high school students. The need to investigate this issue has become more crucial because the subject has also been relatively under researched. Many studies seem to have been more focused on the role of English as a tool of development (e.g., Focho, 2011) or, lately, as a global language as it relates to varieties of World Englishes (e.g., Ngo, 2015; Pham \& Ton, 2010).

With this in mind, this study seeks to explore the perceptions of youths (senior high school students) about the aforementioned issue from a proportional number of participants of five schools in an Indonesian city. As a case in point, this study will involve 333 students from Salatiga, Central Java. While the city is small (with a total of 173.874 people in a 2012 census, Penduduk dan Ketenagakerjaaan, 2013, p.45), it is known to be one of the Indonesian cities in Java with a relatively high proportion of Christians and rated as the most tolerant towards religious diversity in the country.

This study has two main objectives, i. e. (1) to find out about high school students' perceptions towards the impact of English on Indonesian language and culture, and (2) to identify factors affecting the perceptions by examining the demographic variables of gender, major/ study stream, high-school, place of origin, and religion. Conducted on a wider scope, this research is expected to reveal a clearer picture of students' perceptions of the impact of English on national languages and cultures, a paramount issue in regard with multilingualism and identity in developing countries. 


\section{Literature Review}

\section{Indonesian language as a national language and symbol}

The Indonesian language, or Bahasa Indonesia, serves as the national language in Indonesia. It is reported to have been successfully adopted as the national language of Indonesia considering the numbers of people who describe themselves as mother tongue speakers of the language (Montolalu \& Suryadinata, 2007, p.48 as cited in Kirkpatrick, 2009). As the main medium of the country's state administration, education, media and communication, the Indonesian language may even be regarded as one of the most successfully imposed languages in the world.

Indonesian, as a national symbol,also has a crucial role in unifying the country's diverse communities. Zacharias (2012, p.233) believes that "in a country with hundreds of local languages, a strong lingua franca, [Indonesian] is crucial to unify the hundreds of ethnic groups and local languages". Originally only a dialect of Malay, it has now grown into a major language influenced by Indonesia's many local languages and represents the country's national culture (see Murtisari, 2015).

With the prominent role of Indonesian, the Indonesian government has made various efforts to maintain the language, especially through its national center for language planning (now Badan Pengembangan dan Pembinaan Bahasa). In a recent press release, the center stated that foreign languages, especially English, has "permeated various aspects of the people's and nation's lives". It also affects the development of Indonesian,so that it makes "increasingly less room" for the use of the national language (Badan Bahasa Kementrian Pendidikan dan Kebudayaan, 2015).

Several factors other than globalisation have been identified to further contribute to the permeation of English into the Indonesian language. One of these is the sociolinguistic factor that English is considered to be a symbol of social pride. Sadtono (2013, p.46) believes that many Indonesians seem to think that "if they can sprinkle their L1 with English words, people would think that [they] belong to the middle or upper-middle class". This factor seems to encourage the "unnecessary" use of English in Indonesian advertisements and media despite their frequent inaccuracies (e.g., a well-known fast-food franchise in Indonesia wrote safety your hunger to mean satisfy your hunger). Although English is only a foreign language in the country, this increasing use of the language is often seen as a threat to the maintenance of Indonesian as the country's national language and symbol. The concern here is apparently beyond how much the foreign language is used; the attitudes and perceptions of the people towards the national symbol seem to be a more serious matter considering its central role in the life of the nation.

\section{Definitions of culture}

Matsumoto (1996, p.16) defines culture as "the set of attitudes, values, beliefs, and behaviors shared by a group of people, but different for each individual, communicated from one generation to the next". It is therefore closely intertwined with how a society operates because, as Wardhaugh points out, it is "in the sense of whatever a person must know in order to function in a particular society" (2010, p.229). Highlighting a different aspect of culture, Schwartz (1992, p.324), believes that it "consists of the derivatives of experience, more or less organized, learned or created by the individuals of a population, including those images or encodements and their interpretations (meanings) transmitted from past generations, from contemporaries, or formed by individuals themselves". In light of these notions of culture, this study may capture the meaning of culture in three different ways: as a shared cognitive blueprint of approaching the world, as a collective behaviour/custom, and/or of observable artifacts. 


\section{The relationships between language and culture}

The relationships between language and culture are inextricable. Paziresh, et al. (2013) suggests that culture and language reinforce each other either directly or indirectly. Essentially, children could learn a particular language and as a result,the language could transfer values and norms owned by a particular society to them. In addition, Sapir as cited in Wardhaugh (2010) asserts that language and culture has a close relationship, so that people cannot understand or appreciate the one unless they know the other.

\section{Previous studies}

In his widely cited study, Bahasa Asing sebagai Kendala Bahasa Indonesia (Foreign Languages as an Obstacle to the Development of the Indonesian Language), Gunarwan (1998) found that his respondents evaluated English speakers more positively than Indonesian speakers for all the traits associated with status/competence, such as "cleverness", "leadership", "discipline", "education" and "social position". This demonstrates that English is seen to carry more status and prestige compared to Indonesian, which Gunarwan believes will impede the development of the national language.

In line with Gunarwan's finding, Hassall et al.'s (2008) study revealed positive attitudes among young Indonesian university students in Central Java (153 respondents) toward Western loan words (WLWs). The study demonstrated a strong tendency among respondents to agree both that "WLWs sound nice" and that "WLWs enrich Indonesian". They also tended to disagree with the belief that"WLWs pollute Indonesian" and that WLWs should be avoided when they can be replaced by non-Western words. Although there was a suggestion of mild ambivalence, Hassall et al. (2008) believe that the responses demonstrated a "clear general liking and acceptance of [W]estern loanwords" (p.69) and that the negative attitude toward WLWs occasionally expressed by Indonesian language planners and some educated people is "not widely shared by young highly educated Indonesians" (p.70). Besides this, this study found that knowledge of WLWs positively affected students' attitudes towards the loan words. No demographic characteristic, including religion, was found to affect students' attitudes. It was only weakly suggested, hence called "a near-finding" (p.75), that Muslims were more likely to agree that Western loan words pollute the Indonesian language than Christians.

Dewi (2014) studied the perceptions of 32 Indonesians consisting of university students, lecturers and teachers in Jogjakarta (Java), towards English in relation to communication and identity. Over a third of these respondents (13) were either English lecturers or teachers (Dewi, personal communication, 1 January 2016). Although 26 out of 32 respondents associated English with "the West" (Dewi, 2014, p.10), only one participant suggested that it had a negative impact on Indonesian. Almost all of these 26 respondents also believed that English "has influenced one's way of thinking positively" (p.17). Furthermore, Dewi's respondents, who were mostly Muslims, did not think that English is related to faith but regarded it to be an advantage for their religion. According to the participants, the language may be used "as a means for spreading Islamic teaching" (p.17) and some believed it can also serve as a tool of "proselytising where they can revise the incorrect public understanding of Islam" (p.12). The participants believed that "only conventional people would hold negative perceptions of English in relation to religion" (p.17). According to Dewi (2014), this finding contradicts the view that Islam is in opposition to English because it is seen to be an aspect of Western culture and saturated with Christian values.

Apart from the above religious issue, the tendency of research findings to show more favour towards English or not enough concern about the vitality of the Indonesian language seems to demonstrate that the Indonesian government has not done enough to maintain the nation- 
al language. For example, according to Sadtono (2013), although the government has made rules to control the pervasive effect of English loanwords on the national language, they do not seem to work well because Indonesian people may not be aware of or simply ignore the rules. This situation is very different from the conclusion of Pan and Seargeant's (2012) study of 907 Chinese people's perception of the impact of English on the Chinese language and culture, which they associate with the success of the Chinese government's language planning. Although some respondents felt a negative impact from English, the study showed" great confidence in the integrity and prosperity of Chinese language and culture" (p.65). According to Pan and Seargeant this may indicate the success of the Chinese government's English language policies, which are reflected in the national slogan "Chinese knowledge as the foundation and Western knowledge for utility"(p.62). Translated into the national curriculum requirements for foreign language teaching, the policies also "[assist] students in their understanding and appreciation of their home culture, while also cultivating a global outlook" and to have" a deepened understanding of Chinese culture" after their high school graduation (ibid, p.65). This is in line with a public discourse in China that English is not a threat to the national language and culture. Pan and Seargeant's study (2012) demonstrates how extensive efforts to promote the Chinese language and culture can help to counterbalance the dominion of English.

\section{Participants}

The respondents of the study were drawn from 5 senior high schools (Sekolah Menengah Atas or SMAs) in Salatiga, Central Java. The selected schools consisted of two public schools, one Islamic state school, and two private schools. In addition to these five schools, another school was chosen for the pilot study. To increase the representativeness of the subjects for this study, the researchers employed a stratified random sampling technique based on the school and students' major/study stream. Three study streams are offered in general high schools, i. e. natural science, social science and language.Furthermore, once the population units were determined, students were selected randomly by their number in the class lists. This study involved $333 \mathrm{stu}-$ dents to represent a total population of around 4000 high school students in 2015 in Salatiga. The participants consisted of 188 Muslims, 103 Protestants, 41 Catholics and 1 Buddhist.

\section{Instrument and data collection}

The data for the present study was collected using a Likert-scalequestionnaire, which consisted of mixed positive and negative statements to elicit students' views of the impacts of English on Indonesian language and culture (see Appendix 1). The questions were designed to probe four areas: linguistic properties and functions, sociolinguistic aspects, culture, and general views about the issue. Two statements, The increasing use of English in Indonesia is a form of colonization of the Indonesian culture (number 10) and The increasing use of English can endanger the Indonesian culture (number 12), were adapted from Pan and Seargeant (2012).

For the purpose of the study, the researchers translated all the statements into Indonesian to ensure that the participants could completely understand the meaning of each statement. After the questionnaire waspiloted and revised, the questionnaire was distributed by three research assistants who had been briefed on the procedures of data collection to ensure the validity of the obtained data.

\section{Data analysis}

For the data analysis, the students' responses were coded and logged into a Microsoft Excel program. For positive statements towards English (no. 1, 4, 6, 8, 9, 11, 14), a score of 4 was 
assigned for strongly agree responses, 3 for agree responses, 2 for disagree responses, and 1 for strongly disagree responses. A reversed coding was used for negative statements (no. $2,3,5,7,10,12,13)$. This process was done by two research assistants under one researcher's supervision. Following this, a descriptive qualitative analysis was done by examining the percentages of each response category. After some reconsiderations, two statements (no.3 and 4) were entirely dropped from the analysis because of some intrinsic problems. With the assistance of a statistician, the response scores of the selected 12 statements were then transferred into SPSS Version 20 and quantitatively analyzed to find out if there was any factor that influenced students' perceptions. An examination using STATA software was also carried out to ensure that the regression results exhibited robust standard errors.

\section{Percentages of students' responses}

On the basis of the average of the means of the responses for all the statements (see Appendix 2), which is 2.69 out of four, the respondents tended to have a somewhat low to moderate positive view towards the impact of English onthe Indonesian language. For a more detailed picture of the survey's findings, this section will describe how the senior high school students responded to the questionnaire items in terms of the percentages of the four Likert scale categories used in the research. In general it was shown that the students tended to be split into two strong camps when responding to negative statements about the impact of English on the Indonesian language. More optimistic responses were revealed in the area of culture but a rather substantial numbers of students were still critical of the language. In spite of the strongly perceived tension between English and Indonesian, the participants showed high favour towards the international language when it came to its utilitarian value.

With respect to English's linguistic contribution to the Indonesian language's functions, the students had moderately high tendencies to favour the global language. From the respondents, there were $73.6 \%$ who agreed or strongly agreed that the global language significantly enhances the functions of Indonesian as a communication tool in various fields (S8). It is interesting that there was also a relatively strong support (65.2\%) for the supposition that English will help to advance the structure of the Indonesian language (S14). While English has been a major source of loan words for Indonesian, Indonesian grammar has been well established from the government's continuous efforts to enhancethe national language. The majority of the respondents of the present study instead seemed to suggest that English is linguistically superior to Indonesian in terms of structure, which Indonesian purists may find somewhat worrying.

\begin{tabular}{|c|c|c|c|c|c|c|}
\hline & $\begin{array}{c}\text { Strongly } \\
\text { Disagree } \\
\quad(\%)\end{array}$ & $\begin{array}{l}\text { Disagree } \\
\quad(\%)\end{array}$ & $\begin{array}{l}\text { TOT } \\
(\%)\end{array}$ & $\begin{array}{l}\text { Agree } \\
(\%)\end{array}$ & $\begin{array}{c}\text { Strongly } \\
\text { Agree } \\
(\%)\end{array}$ & $\begin{array}{l}\text { TOT } \\
(\%)\end{array}$ \\
\hline $\begin{array}{l}\text { 1. Indonesian will be increasingly richer by } \\
\text { using English borrowed words }\end{array}$ & 7.8 & 42.6 & 50.5 & 45.3 & 4.2 & 49.5 \\
\hline $\begin{array}{l}\text { 8. English really helps the functions of } \\
\text { Indonesian language as a communication } \\
\text { tool in various fields (e.g., as sources of } \\
\text { borrowing words for the sake of know- } \\
\text { ledge, culture, sports, and transportation) }\end{array}$ & 1.5 & 15.3 & 16.8 & 72.1 & 1.5 & 73.6 \\
\hline $\begin{array}{l}\text { 13. English influences make Indonesian } \\
\text { language lose its original character }\end{array}$ & 5.4 & 45.3 & 50.8 & 37.2 & 12.0 & 49.2 \\
\hline $\begin{array}{l}\text { 14. English will help to advance the } \\
\text { structure of the Indonesian language }\end{array}$ & 4.8 & 30.0 & 34.8 & 58.6 & 6.6 & 65.2 \\
\hline
\end{tabular}

\section{Findings and Discussion}

Table 1

Indonesian language's linguistic properties and functions 
However, a different response was given to the statement Indonesian will be increasingly richer by using English loan words (S1), which strongly favours the global language. This item has been formulated as such to elicit how far the respondents favour English, rather than more neutrally expressed as "Indonesian will be richer by using English loan words". It was revealed that the respondents were almost equally divided in their responses to S1 (50.5\% negative versus $49.5 \%$ positive). This finding is consistent with the responses to the negative statement English influences make the Indonesian language lose its original character (S13). While as many as $49.2 \%$ did not believe in this, slightly over half (50.8\%) of the respondents agreed or strongly agreed with the suggestion.

These viewpoints show that although the majority of the respondents considered English to be a very positive linguistic resource (see the findings of S8 and S14), about half of the respondents were critical of its potential negative effects toward Indonesian language with the increasing use of the global language. In other words, there were still many students who shared concerns about the adverse impact of English on Indonesian. However, this still left about half of them, which is a very significant number, somewhat overly favouring the influence of English on the national language's word inventory. There seem to be many supporters of the observed trend of borrowing English words.

Table 2 shows that a similar split also extends to their responses to the more sociolinguistic-related statements (S2, S5, S7). As many as $47.1 \%$ of students agreed or strongly agreed that English may better advance someone's status (e.g. s/he can be considered smarter, cooler, or more respectable) compared to Indonesian (S2), while only slightly more respondents $(52.9 \%)$ were against the statement. This shows thata fairly significant number of students regarded English as a status symbol, although this perception was only shared by half of the respondents. This finding confirms observations that English is regarded as a marker of status in Indonesia (Gunarwan, 1998).

Similar to the finding of S2, students were also split in their responses to S5 dan S7, which have a negative tone towards English. From the total number of participants, $49.2 \%$ of them did not believe the escalating use of English will lower Indonesian people's interest in learning the Indonesian language (S5), while $50.8 \%$ were concerned about this issue.A more polarized finding is shown in the students' responses to S7, which is The increasing use of English will gradually marginalize the position of the Indonesian language. Here the students were almost equally divided with more strong views in both camps. While $39.3 \%$ agreed and $9.6 \%$ strongly agreed with the statement, $40.8 \%$ disagreed and $10.2 \%$ strongly disagreed. These results clearly contradict Dewi's study (2014), in which almost none of her respond-

\begin{tabular}{|c|c|c|c|c|c|c|c|}
\hline \multirow[t]{4}{*}{$\begin{array}{r}\text { Table } 2 \\
\text { Sociolinguistics } \\
\text { aspects }\end{array}$} & & $\begin{array}{l}\text { Strongly } \\
\text { Disagree } \\
(\%)\end{array}$ & $\begin{array}{c}\text { Disagree } \\
\quad(\%)\end{array}$ & $\begin{array}{l}\text { TOT } \\
(\%)\end{array}$ & $\begin{array}{c}\text { Agree } \\
(\%)\end{array}$ & $\begin{array}{l}\text { Strongly } \\
\text { Agree } \\
(\%)\end{array}$ & $\begin{array}{l}\text { TOT } \\
(\%)\end{array}$ \\
\hline & $\begin{array}{l}\text { 2. Compared to the Indonesian language, } \\
\text { English may better advance someone's } \\
\text { status (e.g., s/he can be considered } \\
\text { smarter, cooler, or more respectable) }\end{array}$ & 7.8 & 45.0 & 52.9 & 40.5 & 6.6 & 47.1 \\
\hline & $\begin{array}{l}\text { 5. The increasing use of English will lower } \\
\text { Indonesian people's interest in learning the } \\
\text { Indonesian language }\end{array}$ & 7.5 & 41.7 & 49.2 & 41.4 & 9.3 & 50.8 \\
\hline & $\begin{array}{l}\text { 7. The increasing use of English will } \\
\text { gradually marginalize the position of the } \\
\text { Indonesian language }\end{array}$ & 10.2 & 40.8 & 51.1 & 39.3 & 9.6 & 48.9 \\
\hline
\end{tabular}


ents believed that English does not have a negative impact on the Indonesian language. This may be due to the limited size and sampling of the study's participants, which were only for qualitative purposes.

In the area of culture (see Table 3), significantly more students had positive perceptions towards the impact of English, but this does not make it a strong tendency. There were $64.9 \%$ of the respondents who disagreed or strongly disagreed that The increasing use of English can endanger the Indonesian culture (S12), while $60.1 \%$ did not believe that The increasing use of English in Indonesia is a form of colonization of the Indonesian culture (S10). This still left a substantial number of students who were against English use.

However, when asked if they agreed that English will provide opportunities forthe Indonesian culture to be more widely known by international communities (S6), there was overwhelming support for this role of the international language. A total of $87.7 \%$ students $(56.8 \%$ tickedagreed and $30.9 \%$ chose strongly agreed) endorsed this S6 suggestion. This means many students who were concerned about the negative impact of English on the subtance of Indonesian language and culture (see statements with divided responses) nevertheless seemed to believe that English has an advantage as a means or medium to reach the international world.

On the overall impact of English on Indonesian language and culture (S9), $67.6 \%$ either agreed or strongly agreed that the benefits of the global language are bigger than its negative influences. In spite of this positive tendency, this still left a significant number of students $(32.4 \%)$ who were very pessimistic about the effects of English on their national language and culture. Despite such a negative sentiment, it is interesting that respondents had an overwhelming support for the statement that English and Indonesian can beneficially co-exist (S11). As many as $60.4 \%$ agreed and $31.2 \%$ strongly agreed with the positive statement. This suggests that the majority of the students who appeared critical of English in their responses to other statements were still open to the presence of English in Indonesia.There were apparently some mixed feelings towards English among the participants, which is in

\begin{tabular}{l|c|c|c|c|c|c} 
& $\begin{array}{c}\text { Strongly } \\
\text { Disagree } \\
(\%)\end{array}$ & $\begin{array}{c}\text { Disagree } \\
(\%)\end{array}$ & $\begin{array}{c}\text { TOT } \\
(\%)\end{array}$ & $\begin{array}{c}\text { Agree } \\
(\%)\end{array}$ & $\begin{array}{c}\text { Strongly } \\
\text { Agree } \\
(\%)\end{array}$ & $\begin{array}{c}\text { TOT } \\
(\%)\end{array}$ \\
$\begin{array}{l}\text { S6 English will provide opportunities for the } \\
\begin{array}{l}\text { Indonesian culture to be more widely known } \\
\text { by international communities }\end{array}\end{array}$ & 2.1 & 10.2 & 12.3 & 56.8 & 30.9 & 87.7 \\
\hline $\begin{array}{l}\text { S10 The increasing use of English in } \\
\text { Indonesia is a form of colonisation of the } \\
\text { Indonesian culture }\end{array}$ & 9.3 & 50.8 & 60.1 & 29.7 & 10.2 & 39.9 \\
\hline $\begin{array}{l}\text { S12 The increasing use of English can } \\
\text { endanger the Indonesian culture }\end{array}$ & 8.4 & 56.5 & 64.9 & 28.5 & 6.6 & 35.1 \\
\hline
\end{tabular}

\begin{tabular}{l|c|c|c|c|c|c} 
& $\begin{array}{c}\text { Strongly } \\
\text { Disagree } \\
(\%)\end{array}$ & $\begin{array}{c}\text { Disagree } \\
(\%)\end{array}$ & $\begin{array}{c}\text { TOT } \\
(\%)\end{array}$ & $\begin{array}{c}\text { Agree } \\
(\%)\end{array}$ & $\begin{array}{c}\text { Strongly } \\
\text { Agree } \\
(\%)\end{array}$ & $\begin{array}{c}\text { TOT } \\
(\%)\end{array}$ \\
$\begin{array}{l}\text { 9. The benefits of English are bigger than } \\
\text { its negative influences (if any) towards } \\
\text { Indonesian language and culture }\end{array}$ & 4.5 & 27.9 & 32.4 & 61.6 & 6.0 & 67.6 \\
\hline $\begin{array}{l}\text { 11. English and Indonesian can beneficially } \\
\text { co-exist }\end{array}$ & 0.3 & 8.1 & 8.4 & 60.4 & 31.2 & 91.6 \\
\hline
\end{tabular}

Table 4

General view 
line with Hassall et al.'s (2008) study about Western loanwords. This seems to suggest that such ambivalence is not only limited to perceptions/attitudes about foreign loanwords (see section 1.5, ibid, pp.59-60), but also to English as one of the Western languages.

\section{Factors affecting students' perceptions towards the impact of English on Indonesian language and culture}

A statistical test using Version 20 SPSS' Cronbach Alpha was first carried out to measure the internal consistency of the questionnaire. This revealed a score of 0.739 , which is bigger than the minimum 0.7 score for a set of questions to be able to validly measure a variable. Two correlational tests (Pearson and Spearman) later demonstrated that there was no independent variable, which had a strong correlation with any other independent variable. The highest coefficient was 0.599 , which was between the variable "school" and "major". In addition, a regression test showed that the variance inflation factor (VIF) was far lower than the maximum tolerable score (10). Thus it can be concluded that multicollinearity, which may influence the accuracy of statistical significance, is not an issue in this research.

Table 5

Results of Pearson Correlation Test ${ }^{*} p<0.05 ;{ }^{* *} p<0.01$

\begin{tabular}{l|c|c|c|c|c|c} 
& School & Age & $\begin{array}{c}\text { Place of } \\
\text { origin }\end{array}$ & Gender & Religion & Major \\
\hline School & \multicolumn{1}{|c|}{} & & & & & \\
\hline Age & 0.020 & & & & & \\
\hline Place of origin & $0.157^{* *}$ & -0.005 & & & & \\
\hline Gender & $0.059^{* *}$ & 0.045 & $0.123^{*}$ & & & \\
\hline Religion & $0.182^{* *}$ & -0.059 & $0.021^{* *}$ & 0.085 & & \\
\hline Major & $0.592^{* *}$ & 0.096 & $0.209^{* *}$ & -0.027 & $-0.179^{* *}$ & \\
\hline
\end{tabular}

\section{Tabel 6}

Results of individual examination of relationships between dependent and independent variables

\begin{tabular}{l|l}
\multirow{3}{*}{ Major } & Perception \\
\hline \multirow{2}{*}{ High school } & 1.717 \\
\hline \multirow{2}{*}{ Age } & {$[0.163]$} \\
\cline { 2 - 2 } & 1.899 \\
\hline \multirow{2}{*}{ Place of origin } & {$[0.110]$} \\
\hline \multirow{2}{*}{ Gender } & 0.004 \\
\hline \multirow{2}{*}{ Religion } & {$[0.928]$} \\
\cline { 2 - 2 } & 1.073 \\
\hline \multirow{2}{*}{. } & {$[0.343]$} \\
\cline { 2 - 2 } & 0.176 \\
\hline
\end{tabular}

Note: The table shows the individual tests to investigate the relationship between the independent variables and dependent variable. More specifically, an ANOVA test was used for Major, High school, Place of origin. Meanwhile, a t-test and simple regression were used for the Gender and Age variables, respectively. The numbers not in the brackets refer to the $F(t)$ value, while the numbers in the brackets refer to the significance value. ${ }^{*} p<0.1 ;{ }^{* *} p<0.05 ;{ }^{* *} p<0.01$
Furthermore, in order to find out the effects of the independent variables, a t-test was applied to the variable gender, a single regression for age, and ANOVA for the rest of the variables (school, major, place of origin and religion). As shown by Table 6, religion was detected to be a factor, which influences students' perceptions.

Table 6 demonstrates that religion has a significance value of 0.040 . Although the effect size is small, this reliably indicates that Christian and Catholic students tended to have more optimistic views than Muslim students towards English in relation to their national language and culture (there was only one Buddhist student). This is different from Hassall et al.'s (2008) only very weak suggestion that Muslim respondents seemed to express more negative attitudes toward WLWs than Christian participants 
and contradicts Dewi's (2014) finding in which religion (Islam) is not significantly associated with one's perception of English. These different results may be due to the fact that the respondents of the two previous studies, being at least tertiary students, were likely from the country's middle class, who are associated with more access to English and hence more use of the language. In addition to this, Hassall et al.'s Muslim respondents were students of a Christian university and therefore may have been more moderate in their attitudes toward the international language compared to Muslims in general. The respondents of the present research, on the other hand, came from diverse socio-economic backgrounds. With this in mind, it is important for further research to include this socio-economic aspect as a variable.

In addition to a one-way ANOVA test, a multiple regression test using SPSS version 20 was also conducted to examine students' perceptional scores as the dependent variable and all the independent variables (major, age, students' place of origin, gender and religion). From this, none of the variables except the students' major was identified to be a significant factor. As shown by the first column of the table (Results of Multiple Regression), the students' majors negatively influenced students' responses at a regression coefficient of -0.040 and a significance value of 0.055 . Here it was indicated that students studying natural science had a more positive perception compared to those from the social science or language study streams. A multiple regression test using the STATA software program, which allows analyses with robust standard errors, also revealed very similar results (see column 2 of Table 7).

The tendency of natural science students to have more favourable views towards English may have been caused by the fact that they are not normally exposed to social and/or soci-

olinguistic issues as much as those from the social science or language streams. Referring to Hassall et al.'s finding that students' knowledge of Western loanwords positively affected their students attitudes towards such words, it was also possible that the natural science students competence of English may have played a role in this present study. This is because being a prestigious high school study stream, the natural science major is known to attract the best students, including those with better language competence.

\section{Limitations of the study}

It is important to note that the analysis of the major was only based on data from three schools, and the number of respondents with a language major wassmall (16 students) as representative of the population. Furthermore, although a stratified random sampling was applied, limited access to students and their data made it difficult to select more representative strata and participants. Therefore, the present study was only intended to

\begin{tabular}{|c|c|c|}
\hline & \multicolumn{2}{|c|}{ Perception } \\
\hline & (1) & (2) \\
\hline \multirow{2}{*}{ Major } & -0.040 & -0.040 \\
\hline & {$[0.055]^{*}$} & {$[0.070]^{*}$} \\
\hline \multirow{2}{*}{ School } & 0.018 & 0.018 \\
\hline & [0.393] & [0.370] \\
\hline \multirow{2}{*}{ Age } & 0.014 & 0.014 \\
\hline & [0.724] & [0.735] \\
\hline \multirow{2}{*}{ Place of origin } & 0.016 & 0.016 \\
\hline & [0.574] & [0622] \\
\hline \multirow{2}{*}{ Gender } & 0.038 & 0.038 \\
\hline & [0.366] & [0.386] \\
\hline \multirow{2}{*}{ Religion } & 0.036 & 0.036 \\
\hline & {$[0.236]$} & {$[0.230]$} \\
\hline \multirow{2}{*}{ _cons } & 2.385 & 2.385 \\
\hline & {$[0.000]^{* * *}$} & {$[0.000]^{\star * *}$} \\
\hline$R^{2}$ & 0.03 & 0.03 \\
\hline N & 333 & 333 \\
\hline
\end{tabular}

Table 7

Results of Multiple Regression Tests
Note: The first column shows the results of the OLS (ordinary least square) multiple regression while the second column lists the results of multiple regression with a robust standard error. The numbers in brackets are the significance value. ${ }^{*} p<0.1 ;{ }^{* *} p<0.05 ;{ }^{* * *} p<0.01$ 
provide a more complete snapshot of high school students in Salatiga rather than to accurately represent the city's population. This study is not generalisable to high school students of other Indonesian cities due to different demographic traits.

\section{Conclusions}

This study aims to explore high school students' perceptions on the impact of English on, first the Indonesian language, and, second the culture. The study reveals somewhat strongly polarised views towards English in both areas investigated, which reflects significant perceived tensions between English and Indonesian. In spite of this, the participants tended to have very positive perceptions of English as a means to reach out to the international communities and to support the communicative functions of the Indonesian language. There was also an overwhelming consensus that English may beneficially co-exist in the country although many believed that the language has anegative impact on Indonesian. Unlike previous studies, this research also detected religion and major as significant factors affecting students' perceptions of English in relation to their national language and culture. Involving more respondents from various community strata, this present study shows different insights of Indonesian people's perceptions of English compared to those demonstrated by previous studies. It is important to note that although this study demonstrates more critical views of English compared to the previous research, nearly half of the students, which is a significant number, still showed an overly positive view towards English. The fact that nearly half of the respondents supported the suggestion that the Indonesian language would be increasingly richer by using English loan words and that English may better advance one's status than Indonesian is apparently not something desirable for the cultivation of Indonesian. More research is necessary to find out if high school students in other cities also share a similar perception. Drawing on the present research findings, however, the government's current policy of reducing the amount of English taught in high school does not seem to have been an effective measure to better protect the Indonesian language. In the first place, English comes from everywhere and is inevitable for the country's development. A more concerted language planning,which addresses various needs of students coming from different academic and social backgrounds is imperative to maintain the Indonesian language, an indispensable national symbol, amid the domination of English, the ever-present global language giant.

\section{References}

1. Badan Bahasa Kementrian Pendidikan dan Kebudayaan [Language Institute of Education and Culture Ministry] [online], 2015. Badan Bahasa Memberikan Penghargaan Penggunaan Bahasa Pada Media Massa Cetak Tahun 2015. [Language Institute Grants Award of Best Language Use to Print Mass Media in 2015]. 29 Des 2015. Available at http://badanbahasa. kemdikbud.go.id/lamanbahasa/berita/1869/ badan $\% 20$ bahasa\%20memberikan $\% 20$ penghargaan $\% 20$ penggunaan $\% 20$ bahasa $\% 20$ pada\%20media\%20massa\%20 cetak\%20tahun\%202015[Accessed 1 February 2016].
2. Dewi, A., 2014. Perception of English in Relation to Communication and Identity: A Study of Indonesian Lecturers, Teachers and Tertiary Students. Journal of Asian Pacific Communication, vol 24, issue 1, Amsterdam: John Benjamin, pp.1-21, D0l:10.1075/ japc.24.1.01dew https://doi.org/10.1075/ japc.24.1.01dew

3. Focho, G. N. 2011. Student Perceptions of English as a Developmental Tool in Cameroon [online]. In: Coleman, $\mathrm{H}$ (eds.), Dreams and Realities: Developing Countries and the English Language, pp.2-25. London: British Council. Available at https://www. teachingenglish.org.uk/sites/teacheng/ 
files/Z413\%20EDB\%20Section07.pdf [Accessed 19 May 2017].

4. Gunarwan, A., 1998. Bahasa Asing sebagai Kendala Bahasa Indonesia[Foreign Languages as an Obstacle to the Development of Indonesian](paper presented at Indonesian Language Congress), VII, 1998. Jakarta.

5. Harmer, J., 2007. Chapter 1: The Changing World of English. The Practice of English Language Teaching. Esgender: Pearson Education Limited, pp.13-24.

6. Hassall, T., Murtisari, E. T., Donnelly, C., \& Wood, J., 2008. Attitudes to Western Loanwords in Indonesian. International Journal of the Sociology of Language, vol 189, Berlin/ New York: Mouton De Gruyter, pp.55-84.

7. Kirkpatrick, A., 2009. English as an Asian Lingua Franca and the Multilingual Model of ELT (revised version of a plenary paper presented at the Hong Kong Association of Applied Linguistics Research Forum).

8. Matsumoto, D., 1996. Understanding Culture. Culture and Psychology. Pacific Grove, CA: Brooks/Cole, pp.11-34.

9. Murtisari, E. T., 2015. Indonesian and Translation: National Identity in the Global Border Contests. International Journal of Indonesian Studies (IJIS), vol 2, Autumn issue, Melbourne: Monash University, pp.70-80.

10. Ngo, P. L. H., (2015). An investigation into Vietnamese Teachers' and Students' Perception of English as a Lingua Franca (thesis) [online]. University of Southampton. Available at http://englishagenda. britishcouncil.org/sites/ec/files/Phuong_ Ngo_SummaryMA.pdf [Accessed 29 September 2015].

11. Onishi, N., (2010, July 25). As English Spreads, Indonesians Fear for their Language [online]. New York Times. Available at http://www.nytimes.com/2010/07/26/ world/asia/26indo.html?pagewanted=all\&_ $r=0$ [Accessed 29 September 2014].

12. Pan, L., \& Seargeant, P., 2012. Is English a Threat to Chinese Language and Culture? English Today, vol 28, issue 3, Cambridge: CUP, pp.60-66,
13. Paziresh, A., Shojaie, F., \& Shokrollahi, R., 2013. English Globalization Issues, Impacts and Challenges to Culture and Language in Islamic Contexts Especially Iran. The Iranian EFL Journal, vol 9, issue 4, Cebu: The Iranian EFL Journal Press, pp.113-126.

14. Pham, H. H., \& Ton, N. N. H., 2010.

Vietnamese Teachers' and Students' Perceptions of Global English. Language Education in Asia, vol 1, Pnom Penh: CamTESOL, pp.48-61.

15. Robson, M. 2013. Foreword. The English Effect. In:The Impact of English, What It's Worth to the UK and Why It Matters to the World [online]. P.2 The British Council. Available at https://www.britishcouncil.org/ sites/default/files/english-effect-report-v2. pdf [Accessed 29 September 2014].

16. Sadtono, E., 2013. English Tsunami in Indonesian. Beyond Words, vol 1, issue 1, Surabaya: Widya Mandala University, pp.37-67.

17. Penduduk dan Ketenagakerjaan [Population and Employment]. Salatiga dalam Angka [Salatiga in Figures], 2013. Badan Pusat Statistik Salatiga. Salatiga: CV Putra Karya, pp.45-78.

18. Schwartz, T., 1992. Anthropology and Psychology: An Unrequited Relationship. In: Schwarts, T., White, G., and Lutz, C. (eds). New Directions in Psychological Anthropology. Cambridge: CUP, pp.324-349.

19. Sugiharto, S., 2002. Bahasa Indonesia and Its Borrowing of Foreign Words [online]. The Jakarta Post. Available at http://www. thejakartapost.com/news/2002/10/28/ bahasa-indonesia-and-its-borrowingforeign-words.html\#sthash.9blZx286.dpuf [Accessed 29 September 2014].

20. Wardhaugh, R., 2010. Chapter 9 - Words and Culture. An Introduction to Sociolinguistics (6 $6^{\text {th }}$ ed.). Chichester: Blackwell Publishing Ltd., pp.229-252.

21. Zacharias, N. T., 2012. EFL Student's Understanding of Their Multilingual English Identities. Electronic Journal of Foreign Language Teaching, Vol 9, Issue 2, Singapore: NUS, pp.233-244. 


\section{The Questionnaire}

\section{DATA RESPONDEN}

Umur

Jenis kelamin

Daerah asal

Agama

\section{DAFTAR PERNYATAAN}

Berikut ini adalah beberapa pernyataan tentang pengaruh Bahasa Inggris terhadap Budaya dan Bahasa Indonesia Silahkan tandai $\sqrt{ }$ salah satu kotak yang sesuai pendapat Anda.

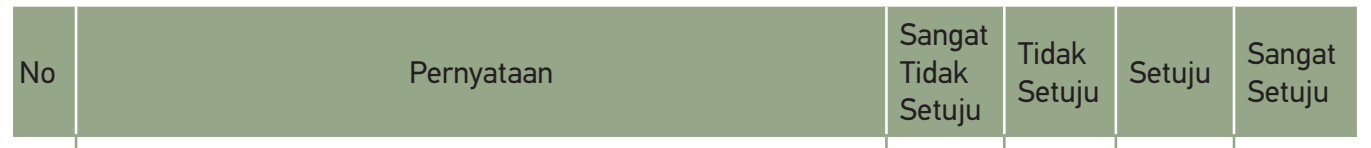

.

Bahasa Indonesia akan semakin kaya dengan menggunakan kata-kata yang dipinjam dari Bahasa Inggris.

2. Dibandingkan Bahasa Indonesia, Bahasa Inggris bisa lebih meningkatkan status seseorang (dianggap lebih pintar, lebih keren, atau lebih terhormat).

3. Semakin meningkatnya penggunaan Bahasa Inggris bisa membuat Bangsa Indonesia kehilangan identitasnya.

4. Semakin meningkatnya penggunaan Bahasa Inggris tidak akan mempengaruhi bahasa dan budaya Indonesia secara mendasar.

Indonesia.

6.

Bahasa Inggris akan membuka peluang agar Budaya Indonesia dapat dikenal lebih luas oleh masyarakat internasional.

7. Semakin meningkatnya penggunaan Bahasa Inggris lamban laun akan menggeser posisi Bahasa Indonesia.

\begin{tabular}{l|l|l|l|l} 
8. & $\begin{array}{l}\text { Bahasa Inggris sangat membantu fungsi Bahasa Indonesia } \\
\text { sebagai alat komunikasi dalam berbagai bidang. (contoh: } \\
\text { sebagai sumber kata pinjaman untuk ilmu pengetahuan, } \\
\text { budaya, olahraga, transportasi) }\end{array}$ & & & \\
\hline 9. & $\begin{array}{l}\text { Manfaat Bahasa Inggris lebih besar dibanding pengaruh } \\
\text { negatifnya (bila ada) terhadap Bahasa dan Budaya Indonesia. }\end{array}$ & & & \\
\hline 10. & $\begin{array}{l}\text { Semakin meningkatnya penggunaan Bahasa Inggris di Indonesia } \\
\text { adalah suatu bentuk penjajahan terhadap Budaya Indonesia. }\end{array}$ & & & \\
\hline 11. & $\begin{array}{l}\text { Bahasa Inggris dan Bahasa Indonesia bisa hidup } \\
\text { berdampingansecara menguntungkan. }\end{array}$ & & & \\
\hline 12 & $\begin{array}{l}\text { Semakin meningkatnya penggunaan Bahasa Inggris bisa } \\
\text { membahayakanBudaya Indonesia. }\end{array}$ & & & \\
\hline 13. & $\begin{array}{l}\text { Pengaruh Bahasa Inggris membuat Bahasa Indonesia } \\
\text { kehilangan ciri aslinya. }\end{array}$ & & & \\
\hline 14. & $\begin{array}{l}\text { Bahasa Inggris akan membantu meningkatkan tata bahasa/ } \\
\text { struktur dari Bahasa Indonesia. }\end{array}$ & & & \\
\hline
\end{tabular}




\section{The Mean of Responses on the Impact of English on Indonesian Language and Culture}

\begin{tabular}{|c|c|c|}
\hline No & Questions & Mean \\
\hline 1. & $\begin{array}{l}\text { Bahasa Indonesia akan semakin kaya dengan menggunakan kata-kata yang dipinjam dari } \\
\text { Bahasa Inggris. } \\
\text { (Indonesian will be increasingly richer by using English borrowed words.) }\end{array}$ & 2.46 \\
\hline 6. & $\begin{array}{l}\text { Bahasa Inggris akan membuka peluang agar Budaya Indonesia dapat dikenal lebih luas oleh } \\
\text { masyarakat internasional. } \\
\text { (English will provide opportunities forthe Indonesian cultureto be more widely known by } \\
\text { international communities) }\end{array}$ & 3.17 \\
\hline 8. & $\begin{array}{l}\text { Bahasa Inggris sangat membantu fungsi Bahasa Indonesia sebagai alat komunikasi dalam } \\
\text { berbagai bidang. (contoh: sebagai sumber kata pinjaman untuk ilmu pengetahuan, budaya, } \\
\text { olahraga, transportasi) } \\
\text { (English really helps the functions of Indonesian language as a communication tool in various } \\
\text { fields (e.g., as sources of borrowing words for the sake of knowledge, culture, sports, and } \\
\text { transportation). }\end{array}$ & 2.93 \\
\hline 9. & $\begin{array}{l}\text { Manfaat Bahasa Inggris lebih besar dibanding pengaruh negatifnya (bila ada) terhadap } \\
\text { Bahasa dan Budaya Indonesia. } \\
\text { (The benefits of English are bigger than its negative influences (if any) towards the Indonesian } \\
\text { language and culture. }\end{array}$ & 2.69 \\
\hline 11. & $\begin{array}{l}\text { Bahasa Inggris dan Bahasa Indonesia bisa hidup berdampingan secara menguntungkan. } \\
\text { (English and Indonesian can beneficially co-exist) }\end{array}$ & 3.23 \\
\hline 14. & $\begin{array}{l}\text { Bahasa Inggris akan membantu meningkatkan tata bahasa/struktur dari Bahasa Indonesia. } \\
\text { (English will help to advance structures of the Indonesian language.) }\end{array}$ & 2.67 \\
\hline 2. & $\begin{array}{l}\text { Dibandingkan Bahasa Indonesia, Bahasa Inggris bisa lebih meningkatkan status seseorang } \\
\text { (dianggap lebih pintar, lebih keren, atau lebih terhormat). } \\
\text { (Compared to the Indonesian language, English may better advance someone's status (e.g., s/ } \\
\text { he can be considered smarter, cooler, or more respectable). }\end{array}$ & 2.54 \\
\hline 5. & $\begin{array}{l}\text { Semakin meningkatnya penggunaan Bahasa Inggris akan menurunkan minat orang } \\
\text { Indonesia untuk belajar Bahasa Indonesia. } \\
\text { (The increasing use of English will lower Indonesian people's interestin learning the Indonesian } \\
\text { language.) }\end{array}$ & 2.47 \\
\hline 7. & $\begin{array}{l}\text { Semakin meningkatnya penggunaan Bahasa Inggris lamban laun akan menggeser posisi } \\
\text { Bahasa Indonesia. } \\
\text { (The increasing use of English will gradually marginalize the position of the Indonesian } \\
\text { language.) }\end{array}$ & 2.52 \\
\hline 10. & $\begin{array}{l}\text { Semakin meningkatnya penggunaan Bahasa Inggris di Indonesia adalah suatu bentuk } \\
\text { penjajahan terhadap Budaya Indonesia. } \\
\text { (The increasing use of English in Indonesia is a form of colonization of the Indonesian culture.) }\end{array}$ & 2.59 \\
\hline 12. & $\begin{array}{l}\text { Semakin meningkatnya penggunaan Bahasa Inggris bisa membahayakan Budaya Indonesia. } \\
\text { (The increasing use of English can endanger the Indonesian culture.) }\end{array}$ & 2.67 \\
\hline 13. & $\begin{array}{l}\text { Pengaruh Bahasa Inggris membuat Bahasa Indonesia kehilangan ciri aslinya. } \\
\text { (English influences make the Indonesian language lose its original character.) }\end{array}$ & 2.44 \\
\hline & Average & 2.69 \\
\hline
\end{tabular}




\section{Santrauka}

Elisabet Titik Murtisari, Calvin Gai Mali. Anglụ kalbos jitaka indoneziečių kalbai ir kultūrai: kaip ją suvokia vidurinès mokyklos (gimnazijos) moksleiviai

Šis darbas tiria Indonezijos vidurinių mokyklų moksleivių suvokimą apie tai, kokią jtaką indoneziečiu kalbai ir kultūrai daro anglų kalba, esant tam tikram susirūpinimui dè svetimos kalbos dominavimo ir šalies pastangoms stiprinti ir palaikyti nacionalinę kalbą. Šiame tyrime užpildydami Likerto klausimyną dalyvavo 333 moksleiviai iš penkiu Salatigos ir kitu Centrinès Javos mokyklų. Priešingai nei ankstesni panašios problemos tyrimai Indonezijos kontekste, ši studija demonstruoja ryškiai nevienodą respondentų reakciją i anglų kalbos ¡̨taką. Studentu religiniai isitikinimai ir pagrindinis studijų dalykas irgi pasirodè esą reikšmingi veiksniai, darantys i̇taką ju atsakymams. Apskritai, šis tyrimas atskleidžia didesnes įtampas tarp nacionalinès ir anglu kalbų ir kultūrų, nei ankstesni tyrimai.

\section{About the Authors}

\section{Titik Murtisari, Elisabet}

$\mathrm{PhD}$, senior lecturer at the Faculty of Language and Literature, Universitas Kristen Satya Wacana, Central Java, Indonesia.

\section{Academic interests}

Translation, pragmatics in translation, translation in language learning/ teaching, language and identity.

\section{Address}

Faculty of Language and Arts, Universitas Kristen Satya Wacana, Jl. Diponegoro 52-60 Salatiga Indonesia 50711.

\section{E-mail:}

etmurtisari@yahoo.com.au; elisabet.murtisari@ staff.uksw.edu

\section{Calvin Gai Mali, Yustinus}

MA (Education), lecturer at the Faculty of Language and Literature, Universitas Kristen Satya Wacana, Central Java, Indonesia.

\section{Academic interests}

English education, second language acquisition, and education techonology.

\section{Address}

Faculty of Language and Arts, Universitas Kristen Satya Wacana, Jl. Diponegoro 52-60 Salatiga Indonesia 50711.

\section{E-mail:}

yustinus.calvin@staff.uksw.edu; calvin.yustinus@ yahoo.com 